\title{
Eating Habits and their Associations with Obesity and Underweight in Preschool Children
}

\author{
Nahla Ali ABD-Elrahman*, Sonia Saleh El Marasy**, Afaf Abd El Fattah \\ Tawfik*, Hanaa Hussein Elsayd* and Alaa Osama Aboraya**
}

*National Nutrition Institute

** Faculty of Home Economics, Helwan University

Correspondence Address: Prof. Hanaa H Elsayed ; Nutritional Chemistry and Metabolism Department, National Nutrition Institute, 16 Kasr El Aini street, Cairo, Egypt.- Email address: hanaa_hamad2003@yahoo.com - Cell Tel: +20 01008825869

\section{ABSTRACT}

7 he defective nutritional habits remains a serious problem of children under five years of age. Bad dietary intake causes malnutrition, which leads to 1 many complications. This study amid to give information about diet quality of underweight and obesity of some Egyptian preschool children. The study was purposed as included (60) preschooler aged 2-<6 years old, with a turbulent linear growth, randomly selected from the outpatient clinic of National Nutrition Institute (NNI) and (30) healthy case in the same age and sex as a control group. All participants were subjected to the baseline assessment (dietary intake including "Twenty four-hour recall "method and "food frequency questionnaire"; anthropometric measurements including weight and height; lab investigation including hemoglobin, serum TSH, T4, T3 vitamin A, and D, concentration. Results showed that mean weight for age $Z$ score is significantly lower among the underweight and higher of obese than the control group. Dietary intake analysis showed that mean intake of all macronutrients was the highest in obesity while micronutrients was lower in both malnutrition groups compared to the control group. All blood values of Hb, TSH, T3, and vitamins A or D were lower among the two malnutrition groups and control group. T4 was higher in underweight group than other groups. Conclusion, it seemed that dietary intake deficiency of several nutrients of malnutrition children intake might play an important role of their growth. Preventive strategies to protect against malnutrition and promote healthy eating consumption recommended.

Key words: Diet Quality - Malnutrition - preschool children 


\section{INTRODUCTION}

Milosevic, et al., (2012) showed that the food choice practices typically viewed as patterns of human activity or as a dynamic process that integrated within the social structures of these patterns. Bad eating habits, children's diet is rich in calories, at the same time being deficient in elements necessary for proper development such as: vitamins, macro- and microelements, fiber, and unsaturated fatty acids. The examples of such bad eating behaviors are eating in front of the $\mathrm{TV}$, snacking between meals, most often highly processed and calorie-rich foods, skipping breakfasts, drinking sugarsweetened beverages (Inadera, 2013).

A pattern of consumption and diet can be modifiable risk factors, and its influence on health, (So et al., 2017; Johnson et al., 2018). The analysis of dietary patterns has been identified as a more realistic representation of dietary habits, (Cunha et al., 2018), since it takes into account the complex interactions between nutrients and other components of a diet, thus making interventions to alteration eating habits possible (So et al., 2017; Johnson et al., 2018).

Few studies (Moreira et al., 2010 and Craig et al., 2010) have found the relationship between sweets, unhealthy snacks, low-quality dietary patterns, and weight among children and this referred to some culture. Obesity is the positive energy balance caused by accumulation of body fat, which means that more energy consumed than expended during metabolism. The most popular method to assess whether the body mass is adequate is the body mass index (BMI) which is calculated from a person's weight and height (TIOTF, 2005). Increased risk of cardiovascular disease, diabetes, hyperlipidemia, hypertension, and metabolic syndrome are physical and psychological problems related to childhood obesity, (Andrade, et al., 2010; Weiss and Caprio, 2005) as well as poor body image, self-esteem and overall well-being (Swencionis and Rendell, 2012).

Malnutrition is among children in poor countries, and a significant proportion of affected children suffer and die if they 
untreated (Cheung, 2006). When World Health Organization (WHO) growth standards are used, the risk attenuated for children smaller weight (Black et al., 2008)

This study will investigate to the dietary patterns of both underweight and obese Egyptian preschool children as compared to normal children.

\section{SUBJECTS \& METHODS}

This is a study, carried out on 90 preschool children aged (2$<6$ years) attending outpatient clinic of National Nutrition Institute (NNI), Cairo during the period January 2019 to July 2019. Children were divided into three groups: Group control (normal group), this group (30 healthy children) matched age and sex with the other two groups (obesity and underweight) which were classified by weight for age.

After taking verbal consent from the parents, of each the studied cases as well as the controls subjected to the following procedures.

- Assessment of the social class of the family estimated according to Fahmy and El Sherbeni (1983).

- Dietary Intake: the study participants assessed by means of two quantitative nonconsecutive 24-hour dietary recalls (one for a weekday and the other for a weekend). The energy and main nutrients content of the 24-hour food intake was computed through the food composition tables of the national nutrition institute (NNI, 2006). The vitamin and mineral contents of food and beverages consumed was compared to the recommended nutrient intake based on the report of joint WHO/ FAOExpert Consultation on human vitamin and mineral requirements (2002).

- Dietary pattern " Food Frequency Questionnaire"

This method used to obtain qualitative descriptive information about usual food and beverage consumption pattern for the whole family per week (daily, less than 3 times per week or equal or more than 3 times per week and monthly). 
- $\quad$ Anthropometric measures measured according to standardized methods of the World Health Organization (WHO, 1995). Measurements taken included: The Childs weight, length or height, and their Z-score is calculated. Zscore $($ or SD-score $)=($ observed value - median value of the reference population) / standard deviation value of reference population. $\mathrm{Z}$ score was calculated of weight for age using the computer program ANTHRO [version 1.01 1990].

- Measurement of weight: The body weight measured using the Platform scale (Ghalli et al., 2002).

- Measurement of height or length: The height measured to the nearest centimeter, row data entered separately to the WHO Growth charts for age and sex (Ghalli et al., 2002).

\section{- Laboratory investigations:}

- Collection of Specimens:

- Blood samples.

Collected from fasting children between ( 9 and
10 a. m). $5 \mathrm{ml}$ venous blood samples withdrawn and divided into 2 specimens. The first sample collected in EDTA vacutainer tubes for doing a hemoglobin in whole blood concentration: by Drabkin, (1949). The second sample separated serum by centrifugation (3000 rpm $10 \mathrm{~min}$ ) and were stored frozen at $-70^{\circ} \mathrm{C}$ until analysis done. Serum Zinc measured by the colorimetric method, (Crest Biosystems) according to (Makino, 1991). Serum Calcium: By Colorimetric determination using the kits from bioMerieux France (Kaplan, and Pesce, 1996). Serum TSH, T3, T4: By immunometric assay using ELIZA kit manufactured by BioSource Europe Belgium. TSH (Fisher, 1996), $\mathrm{T} 3$ according to (Wild, 1994) and T4 (Arem and Escalante, 1996). Serum vit. A: By Bieri et al., 
(1979).

25hydroxyvitamin

$\mathrm{D}$

measurement according to

Lensmeyer et al., (2006).

- Statistical data analysis:

Data analyzed by using SPSS (version 16). Data for all variables presented as means with their standard deviations; Comparison of means made using unpaired student's t-test. $\mathrm{P}$ values of $(<0.05)$ were considered significant were identified by Artimage and Berry (1987).

\section{- Ethical considerations:}

An informed consent obtained from the parents of the children before getting them involved in the study according to the rules of the ethics committee of the National Nutrition Institute. The steps of the study, the aim, the potential benefits, and hazards all discussed with the parents.

\section{RESULTS \& DISCUSSION}

Table (1) descripted the sample characteristics (gender, age, and economic class). It showed that the male number was higher than female for normal and underweight groups. While obese children male and female was equal number. In the same table children age was among $2-<6 \mathrm{y}$ as a preschooler. The highest percentage of low economic was in normal and obese groups.

Table (2) showed that there are high significant difference between the three groups as regard their weight, height, body mass index (BMI)-z-score and BMIpercentile. The highest value of weight and height were in obese group. Z-score of obesity group was (3.8) more than -2SD while normal group was (1.4) in normal range (-2 to + $2 S D)$ (WHO, 1995). The obese group was $(100 \%)$ more than $95^{\text {th }}$ percentile, but control group was (80.8) in healthy weight (less than $85^{\text {th }}$ ) according to the learner chart of BMI percentile (Shypailo 2020). Group 3 was less than $5^{\text {th }}$ percentile that means this group underweight according to WHO, (1995). This BMI-calculator automatically adjusts for differences in height, age, and gender, making it is one of the best tools for evaluating a growing child's weight (Shypailo 2020). In practice, HA Z-score or $\mathrm{WH} Z$ Z- 
score are calculated: the differences between the observed values and the growth standards as a fraction or multiple of the SD of the mean values of the standards. Because this SD increases with age, the absolute HA difference (cm) has suggested to be more appropriate in terms of identifying the time course of stunting and appropriate periods for intervention (Leroy et al., 2014).

Data in table (3) observed that obesity group consumed $153 \%$ calorie, $294 \%$ protein, $255 \%$ carbohydrate and $187 \%$ fat from RDA (WHO, 2014) versus $89 \%$ calorie, $84 \%$ protein, $82 \%$ carbohydrate and $87 \%$ fat of control or normal group. While underweight group consumed 33\% calorie, $55 \%$ protein, $54 \%$ carb and $36 \%$ fat from their RDA. A caloric deficit is any shortage in the number of calories consumed relative to the number of calories required for maintenance of current body weight (energy homeostasis). A deficit can be created by reducing input/calories consumed (lower food intake) A deficit can also be created by increasing output without a corresponding increase in input. Increased output created by increasing physical activity (Redman, et al., 2009). While excess calories are stored throughout in body as fat. Excessive fat cells adipose in tissue and accumulation that may impair health', and cause of obesity and overweight is an energy imbalance between calories consumed and calories expended (WHO, 2014).

Dietary protein provides key regulatory of growth control in which playing important roles for the accumulation of proteincontaining structures. Dietary intake through an amino static appetite mechanism, which enables protein intake to meet the demand, the overall metabolic for amino acids for lean tissue growth linked. Regulation of the demand involves a mechanism in which amino acid intake exerts a largely endocrine-mediated anabolic drive on the growth plate of the long bones, which in turn, through passive stretching, activates growth of associated muscles at the level of muscle connective tissue synthesis. This ensures that skeletal muscle growth occurs at a rate and time course, which 
ensures sufficient, muscle mass and strength to allow development of body function with increasing bone length and associated height, and the protein deposition in muscle signals increases in appetite (Millward, 1995).

The quantity of dietary protein affect its ability to stimulate the secretion of insulinlike growth factor I (IGF-I) \{the mediator of growth hormone\}, a hormone that stimulates bone and tissue growth (Dror and Allen, 2011). There was substantial emphasis on protein deficiency as one of the main causes of undernutrition in low-income countries (Semba, 2016). In recent years, however, biological research has argued that the essential amino acids in animalsourced foods (ASFs) "essential" because they cannot synthesized from scratch within the human body - and regulate cellular processes such as growth of bone and skeletal muscle growth (Semba 2016).

Mean fat intake was $187 \%$ of RDA among obese group compared to $36 \%$ of RDA among underweight children. In addition to its function in absorption and transport of fat-soluble vitamins, (some of which are very essential for bone health), fat contains essential fatty acids, which are required for normal growth (Jones and Kubow, 1999).

The present results in table (4) illustrated that the minerals iron lower intake of all groups as compared to their RDI. During childhood, iron deficiency could lead to impaired cognitive and physical functionality and increased risk of mortality (Murray, et al., 2012). Linear growth inhibition is an immediate response to their deficiency; include protein, iron, and $\mathrm{Zn}$. There is evidence that deficiencies of protein, iron and $\mathrm{Zn}$ can occur in the human diet, especially for populations consuming diets based on starchy roots with little or no animal-source foods (ASF). The prevalence of iron and $\mathrm{Zn}$ deficiency is widely believed to be widespread in developing countries because of low intakes of animal products, diets high in phytates, which inhibit iron and $\mathrm{Zn}$ absorption (de Benoist, et al., 2007). Further, zinc deficient makes infants and young children are prone to infections and growth 
retardation (Hess, et al., 2009). The major cause of micronutrient malnutrition is a diet consisting mainly of staple foods and lacking in animal sources (Bouis 2003). Deficiency results from insufficient absorption of iron or excess loss. Absorption tightly regulated in the intestines, depending on the iron status of the individual, the type of iron, and other nutritional factors. Once iron is absorbed, it is well conserved (Beard 2001).

This study highlighted the importance of micronutrients and macronutrients consumption among children. Data in table 4 showed that the calcium was the lowest minerals intake in relation to percentage RDI among all groups, followed by phosphorus intake $(33 \%)$ of underweight versus $(51 \%)$ of normal group, while obese group was $126 \%$. They also had significantly lower mean values for calcium and phosphorus, which have a significant role in bone growth (Alshammari et al., 2017). Calcium intake in this study was extremely low between G1 and G3 as compared to obese group, denoting more compromised calcium bioavailability. There is some limited evidence for phosphate deficiency occurring through a dietary lack (Waterlow, 2006), although phosphate deficiency is likely to be rare. Indeed, average intakes of $\mathrm{P}$ and $\mathrm{Mg}$ from most diets are usually substantially greater than their biological requirements and, if not, increased absorption.

The finding in table 4 indicated that the all studied groups had low intake of vitamins D compared to \% RDA, Vitamin D participates with parathyroid hormone (PTH) in a functional paracrine feedback loop in the growth plate between $1,25(\mathrm{OH}) 2 \mathrm{D}$ and PTH-related protein (PTHrP). Thus 1, 25(OH) 2D decreases PTHrP production, while PTHrP increases chondrocyte sensitivity to $1,25(\mathrm{OH}) 2 \mathrm{D}$ by increasing vitamin $\mathrm{D}$ receptor production (Bach, et al., 2014).

Table (5) showed that the obese group most of them range from $83 \%$ to $100 \%$ intake Bread, Rice, Baked, Indomie, Potatoes chipsey, triangles cheese, Sugar, Soft drinks, and fast food more than three time per day. $17 \%$ only received fresh vegetable more than 
three time in week. $73 \%$ assimilation corn oil less than 3 time/day. These food habit give more calorie for obese. $83 \%$ and $90 \%$ from normal children intake fresh vegetable and cooked vegetable more than 3 time/ day. In addition, fruits represented $87 \%$ consumed of normal group. $50 \%$ from group 3 received lower than three time /day bread. All food intake for underweight group lowest in calorie and other nutrients. These dietary habits of the three groups had their impact on their growth. In addition, when one self-assesses energy intake, under- and over-reporting consumption may occur (Dhurandhar et al., 2015). Dieting is the most described behavioral risk factor for binge eating disorder (BED) onset. It well documented that dieting increases the risk of overeating to counteract the caloric deprivation and, therefore, weight gain over time, but this is more likely to happen during adolescent's stage. Furthermore, some of the abovedescribed psychological risk factors such as body dissatisfaction, perceived pressure to be thin, emotional eating and negative affect interact and mutually reinforce each other, promoting dieting and, therefore, increasing the risk for BED (Stice et al., 2002).

The statistical result in table (6) showed that the mean hemoglobin level, TSH, T3, T4, vitamins $\mathrm{A}$, and $\mathrm{D}$ were within normal rang among the control group. Obesity and underweight groups were lower value of hemoglobin than control group and normal range with percent change -13 and $-20 \%$ respectively. Anemia in young children is a serious concern because it can result in impaired cognitive performance, behavioral and motor development, coordination, language development, and scholastic achievement as well as increased morbidity from infectious diseases (IIPS, 2007).

TSH level in Obesity and underweight groups were decrease in compare G1 but within normal range. While T3 value in-group, two and three was less than control group and normal level. T4 amount showed increase in underweight group with $69 \%$ change compare control group, while obese group was the same value control group. Adaptive 
changes in iodine and thyroid hormone metabolism occur with iodine deficiency, initially conserving iodine within thyroid tissue in association with increased TSH and maintaining T4 and T3 levels (subclinical hypothyroidism), eventually followed by reductions in $\mathrm{T} 4$ (overt hypothyroidism). Thus, in both severely iodine-deficient and moderately iodine-deficient children, as indicated by their urinary iodine concentration, median T4 concentrations can be in the low-normal range, with only a minority identifiable as hypothyroxinaemia

(Zimmermann, et al., 2007). Serum total and free T3 concentrations may not decrease until disease far advanced, because increased TSH concentrations stimulate $\mathrm{T} 3$ release from the thyroid. Thus, the enlargement of the thyroid may precedeanyfallinT3 and any impairment of linear growth (Zimmermann, 2007), and, of these, a recent systematic review identified only two studies which reported on child linear growth, observing no improvements (Zhou, et al., 2013). However, when given T4, hypothyroid iodine-deficient children with goitre, short stature and retarded bone age increased in stature (Hernandez-Cassis, et al., 1995).

Finding of vitamins, A and $\mathrm{D}$ in the same table showed that the reduction value of obese and underweight groups in comparison control group and reference range. Zulet et al., (2008) have reported inverse relationship between vitamin A intake and adiposity. Other studies have also reported inverse correlation between serum retinol and body mass index in morbidly obese subjects (Aasheim, et al., 2008).

Vitamin D is an essential component of bone and mineral metabolism. It plays a significant role in the homeostasis of calcium and phosphorus and is vital for bone mineralization, skeletal growth, and bone health. A normal vitamin $D$ status seems to be protective against musculoskeletal disorders (muscle weakness, falls and fractures), (Pludowski et al., 2013).

\section{CONCLUSION}

The dietary patterns derived from the current study based on a considerable number of children 
could provide practical information for health authorities designing nutritional interventions and preventive strategies targeting obese and underweight children.

\section{REFERENCES}

Aasheim ET; Hofso D;

Hjelmesaeth J; Birkeland KI;

Bohmer T (2008):

Vitamin status in mor-

bidly obese patients: a cross-sectional study. Am J Clin Nutr; 87: 362-9.

Alshammari E; Suneetha E; Adnan M; Khan S; and Alazzeh A (2017):

Growth Profile and Its Association with Nutrient Intake and Dietary Patterns among Children and Adolescents in Hail Region of Saudi Arabia. BioMed Research International, Volume 2017.

Andrade H; Antonio N; Rodrigues D; DaSilva $M$; Pego M; Providencia LA (2010):

High blood pressure in the pediatric age group. Rev Port Cardiol.; 29:413-32
Arem $\mathbf{R}$ and Escalante, $\mathbf{D}$ (1996):

Subclinical hypothyroidism: epidemiology, diagnosis, and significance. Adv. Intern. Med. 1996; 41: 213-51.

\section{Artimage G Y and Berry, WG} (1987):

Statistical Methods 7th Ed. Ames, Iowa Stata University Press, 39- 63.

Bach FC; Rutten KR and Hendriks, K (2014):

The paracrine feedback loop between vitamin D3 $(1,25$ (OH) 2D3) and PTHrP in prehypertrophic chondrocytes. J Cell Physiol 229, 1999 - 2014.

\section{Beard (2001):}

Connor JR. Iron status and neural functioning. Annu Rev. Nutr; 23:41-58

\section{Bieri JG; Tolliver TJ; Catiganu} GL (1979):

Simultaneous determination of a - tocopherol and retinol in plasma or red cell by high-pressure liquid chromatography. AM. J. Clin Nutr32: 2143. 

and Alaa Osama Aboraya

Black RE; Allen LH; Bhutta ZA; Caulfield LE; de Onis M; Ezzati M; Mathers C;Rivera J (2008):

Maternal and child undernutrition: Global and regional exposures and health consequences. Lancet; 371:243-60.

Bouis HE (2003):

Micronutrient fortification of plants through plant breeding: Can improve nutrition in man at low cost? Proc. Nutr. Soc., 62, $403-411$.

\section{Cheung YB (2006):}

Estimation of childhood mortality attributable to poor nutrition using timeupdated variables. Paper presented at the 27th Annual Conference of the International Society for Clinical Biostatistics, Geneva, 27-31.

\section{Craig LC; McNeill G; Macdi-} armid JI; Masson LF; Holmes BA (2010):

Dietary patterns of schoolage children in Scotland: Association with socio- economic indicators, physical activity, and obesity. $\mathrm{Br} \mathrm{J}$ Nutr. 103:319-34.

\section{Cunha DB; Bezerra IN; Pereira RA; Sichieri R (2018): \\ At-home and away-from- home dietary patterns and BMI z-scores in Brazilian adolescents. Appetite; 120:374-380.}

De Benoist B; Darnton-Hill I; and Davidsson L (2007):

Conclusions of the Joint WHO/UNICEF/IAEA/I ZiNCG Interagency Meeting on Zinc Status Indicators. Food Nutr Bull 28, S480 - S484.

\section{Dhurandhar NV; Schoeller D; Brown AW (2015):}

Energy balance measurement: when something is not better than nothing is. Int $\mathrm{J}$ Obes. ; 39:1109- 1113 .

\section{Drabkin (1949):}

The standardization of hemoglobin measurement. Am. J. Med. Sci., 21-710. 
Dror DK and Allen LH (2011):

"The Importance of Milk and other Animal-Source Foods for Children in Low-Income Countries." Food and Nutrition Bulletin 32: 227- 243.

Fahmy $S$ and El-Sherbini AF (1983):

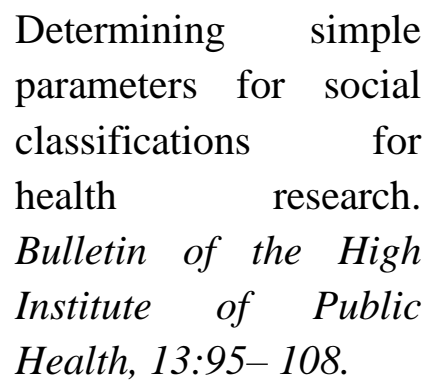

Fisher DA (1996):

"Physiological variation in thyroid hormones. Physiological and pathophysiological considerations." Clin Chem, 42,135-139.

Ghalli I; Salah N; Hussein F; Erfan M; El-Ruby M; Mazen I,sabry M; Abd El-Razik M; Saad M; Hossny L; Ismail S; Abd El-Dayem S (2002):

Egyptian growth curves for infants, children, and adolescents.
Published in: Crecerenel mondo. Satorio A, Buckler JMH and Marazzi N (2008), Ferring Publisher, Italy.

Hernandez-cassis C; cure-cure C; lopez J (1995):

Thyroid dysfunction Europern $\mathrm{J}$ clin lewst 25: 454-6.

Hess SY; Lonnerdal B; Hotz C; Rivera JA; Brown KH (2009):

Recent advances in knowledge of zinc nutrition and human health Food Nutr. Bull., 30, S5 S11.

\section{Inadera H (2013):}

Developmental origins of obesity and type 2 diabetes: molecular aspects and role of chemicals. Environ Health Prev Med.; 18:187195.

International Institute for Population Sciences (IIPS) and Macro International (2007):

National Family Health Survey (NFHS-3), 2005- 
06: India: Volume I.

Mumbai: IIPS.

Johnson L; Toumpakari Z; Papadaki A (2018):

Social gradients and physical activity trends in an obesogenic dietary pattern: Cross-sectional analysis of the UK National Diet and Nutrition Survey 20082014. Nutrients; 10:388.

Jones D \& Kubow S (1999):

Lipid, sterols and their metabolism. In: Krause's Food, Nutrition and Diet Therapy, Mahan K \& Escott-Stump S (eds); 10th edition, Saunders company, chapter (4) 6797.

\section{Kaplan LA and Pesce A (1996):}

J.:"Clinical Chemistry", Mos by Ed.

\section{Lensmeyer GL; Wiebe DA;}

\section{Binkley N (2006):}

HPLC method for 25hydroxyvitamin D measurement: comparison with contem- porary assays. Clin Chem; 52:1120-6.

Leroy JL; Ruel M; and Habicht J P (2014):

Linear growth deficit continues to accumulate beyond the first 1000 days in low- and middle-income countries: global evidence from 51 national surveys. J Nutr 144, 1460 -1466.

Makino T (1991):

Estimation of Serum Zinc. Clin Chem Acta; 197: 209-220. 22.

Millward D J (1995):

A protein-stat mechanism for the regulation of growth and maintenance of the lean-body mass. Nutr Res Rev 8, $93-120$.

\section{Milosevic J I; Zezelj M; Gorton} W; Barjolle; D (2012):

Understanding the motives for food choice in Western Balkan Countries.

Appetite, 58: 205-214. 

and Alaa Osama Aboraya

Moreira P; Santos S; Padrão P; Cordeiro T; Bessa M; Valente $\mathbf{H}$ (2010):

Food patterns according to sociodemographic,

physical activity, sleeping and obesity in Portuguese children. Int J Environ Res Public Health; 7:1121-38.

Murray CJL; Vos T; Lozano R; Naghavi $M$; Flaxman AD; Michaud C; Ezzati M; Shibuya K; Salomon JA; Abdalla S (2012):

Disability-adjusted life years (DALYs) for 291 diseases and injuries in 21 regions, 1990-2010: A systematic analysis for the Global Burden of Disease Study 2010. Lancet 2012, 380.

\section{NNI (2006):}

National Nutrition Institute Food Composition Tables, Cairo, A.R.E., 2006.

\section{Pludowski P; Holick MF; Pilz S} (2013):

Vitamin D effects on musculoskeletal health, immunity, autoimmunity, cardiovascular disease, cancer, fertility, pregnancy, dementia, and mortality - a review of recent evidence. Autoimmune Rev; 12:976-989.

\section{Redman LM; Heilbronn LK; Martin CK; de Jonge L; Williamson DA; Delany JP; Ravussin E (2009):}

"Metabolic and Behavioral Compensations in Response to Caloric Restriction: Implications for Maintenance of Weight Loss' PLOONE. 4. doi :10.1371/ journal. Pone.

Semba RD (2016):

"The Rise and fall of Protein Malnutrition in Global Health." Annals of Nutrition and Metabolism 69: $79-88$

Shypailo R J (2020):

Age - based Pediatric Growth Reference Chares. Retrieved 7/19/2020 from the Baylor College of Medicine, Children's Nutrition Research Center, Body Composition Laboratory Web Site: http://www.bcm.edu/bodyc 
omplab/BMIapp/BMI-

calculator - kids.html

So E; Kim J; Joo S (2017):

Association of dietary patterns with overweight risk and all-cause mortality in children with cancer. Nutr Res Pract; 11:492499.

\section{Stice E; Presnell K; Spangler D} (2002):

Risk factors for binge eating onset in adolescent girls: a2-year prospective investigation. Health Psychol.; 21:131-8.

\section{Swencionis C and Rendell SL} (2012):

The psychology of obesity. Abdom Imaging; $37: 733-35$.

\section{Third International Obesity} Task Force (TIOTF) (2005):

European Union Platform Briefing Paper. Brussels, 15.

Waterlow J C (2006):

Protein Energy Malnutrition. London: SmithGordon \& Co Ltd.
Weiss $R$ and Caprio $S$ (2005):

The metabolic consequences of childhood obesity. Best Pract Res Clin Endocrinol Metab.; 19:405-19.

WHO (1995):

Human Vitamin and Mineral raquirements. A Report of a joint WHO expert consultation.

Bangkok, Thailand.

WHO (2014):

Scurvy and its prevention and control in major emergencies.

WHO/FAO (2002):

Human Vitamin and Mineral requirements. A Report of a joint FAO/WHO expert consultation. Bangkok, Thailand.

Wild D (1994):

Immunoassay Handbook, Stockton Press p339.

Zhou k; Victora CG; Walker SP; Bhutta ZA; Christian P; de Onis M (2013): 

and Alaa Osama Aboraya

$\begin{array}{lrl}\text { Maternal and child } & \text { concentrations and impro- } \\ \text { undernutrition } & \text { and } & \text { ves somatic growth. J Clin } \\ \text { overweight in low-income } & \text { Endocrinol Metab; 92, 437- } \\ \text { and } \quad \text { middle-income } & 442 .\end{array}$
countries. Lancet. ; $382: 427-51$.

\section{Zulet AM; Puchau B; Hermsdorff HHM; Navarro C; \\ Martinz JA (2008):}

Zimmermann M B; Jooste P L; and Mabapa N S (2007):

Treatment of iodine Vitamin A intake is deficiency in school-age children increases insulininversely related with like growth factor (IGF)-I adiposity in healthy young adults. J Nutr Sci Vitaminol and IGF binding protein-3 (Tokyo); 54: 347-52. 
Table (1) Sample characteristics

\begin{tabular}{|c|c|c|c|c|c|c|c|}
\hline \multirow[t]{2}{*}{$\begin{array}{c}\text { Personal } \\
\text { characteristic } \\
\mathbf{S}\end{array}$} & \multirow[t]{2}{*}{ Categories } & \multicolumn{2}{|c|}{$\begin{array}{l}\text { Normal } \\
\text { children } \\
(N=\mathbf{3 0})\end{array}$} & \multicolumn{2}{|c|}{$\begin{array}{c}\text { Obese } \\
\text { children } \\
(N=30)\end{array}$} & \multicolumn{2}{|c|}{$\begin{array}{c}\text { Underweight } \\
\text { children } \\
(N=\mathbf{3 0})\end{array}$} \\
\hline & & No & $\%$ & No & $\%$ & No & $\%$ \\
\hline \multirow[t]{2}{*}{ Number } & Male & 18 & $60 \%$ & 15 & $50 \%$ & 18 & $60 \%$ \\
\hline & Female & 12 & $40 \%$ & 15 & $50 \%$ & 12 & $40 \%$ \\
\hline \multirow[t]{3}{*}{ Age groups } & 2-3 year & 9 & $30 \%$ & ------- & ----- & 12 & $40 \%$ \\
\hline & 4-5 year & 18 & $60 \%$ & 18 & $60 \%$ & 9 & $30 \% 3$ \\
\hline & $>5-<6$ year & 3 & $10 \%$ & 12 & $40 \%$ & 9 & $0 \%$ \\
\hline \multirow{3}{*}{$\begin{array}{l}\text { Economic } \\
\text { class }\end{array}$} & Low & 18 & $60 \%$ & 16 & $55 \%$ & 14 & $45 \%$ \\
\hline & Middle & 12 & $40 \%$ & 14 & $45 \%$ & 16 & $55 \%$ \\
\hline & High & ----- & ---- & ----- & ---- & ---- & ------- \\
\hline
\end{tabular}

Table (2) Growth ideal, Weight, Height, BMI- Z-Score, and BMI -Percentile $($ mean $\pm \mathrm{SE}$ ) for age preschool children

\begin{tabular}{|c|c|c|c|c|}
\hline $\begin{array}{c}\text { Parameters/ } \\
\text { Groups }\end{array}$ & $\begin{array}{c}\text { Normal } \\
\mathbf{( N = 3 0 )}\end{array}$ & $\begin{array}{c}\text { Obesity } \\
\mathbf{( N = 3 0 )}\end{array}$ & $\begin{array}{c}\text { Underweight } \\
(\mathbf{N}=30)\end{array}$ & $\begin{array}{c}\boldsymbol{P} \\
\text { value }\end{array}$ \\
\hline Growth ideal & $17.2 \pm 0.3$ & $12.2 \pm 0.2$ & $10.9 \pm 0.3$ & $\begin{array}{c}0.000 \\
(8.85 \mathrm{E}-28)\end{array}$ \\
\hline Weight & $17.3 \pm 0.4$ & $36.9 \pm 0.4$ & $8.3 \pm 0.3$ & $\begin{array}{c}0.000 \\
(1.89 \mathrm{E}-71)\end{array}$ \\
\hline Height & $99.0 \pm 1.2$ & $113 \pm 0.8$ & $95.2 \pm 1.5$ & $\begin{array}{c}0.000 \\
(2.23 \mathrm{E}-17)\end{array}$ \\
\hline BMI Z-Score & $1.4 \pm 0.1$ & $3.8 \pm 0.1$ & $-12.9 \pm 1.5$ & $\begin{array}{c}0.000 \\
(2.28 \mathrm{E}-24)\end{array}$ \\
\hline BMI Percentile & $80.8 \pm 1.8$ & $100 \pm 0.01$ & 0 & $\begin{array}{c}0.000 \\
(7.75 \mathrm{E}-80)\end{array}$ \\
\hline
\end{tabular}

Less than the $5^{\text {th }}$ percentile $=$ Underweight; $5^{\text {th }}$ to less than the $85^{\text {th }}$ percentile $=$ Healthy Weight; $85^{\text {th }}$ to less than the $95^{\text {th }}$ percentile= Overweight; Equal to or greater than the $95^{\text {th }}$ percentile $=$ Obese $;$ sig. $(P<0.05)$. Normal -2 to $+2 S D$. Tall $:+2 S D(W H O, 1995)$ 
Table (3) Mean and percent from RDA of Macronutrients intake for normal cases, obese and underweight children $(\mathrm{No}=30 /$ each)

\begin{tabular}{|l|c|c|c|}
\hline $\begin{array}{l}\text { Parameters/ } \\
\text { Groups }\end{array}$ & $\begin{array}{c}\text { Normal } \\
\text { G1 }\end{array}$ & $\begin{array}{c}\text { Obesity } \\
\text { G2 }\end{array}$ & $\begin{array}{c}\text { Underweight } \\
\text { G3 }\end{array}$ \\
\hline \multicolumn{4}{|c|}{ Macronutrients intake } \\
\hline Calorie (kcal) & $1248 \pm 1.4$ & $2135 \pm 65.7$ & $456.5 \pm 29.5$ \\
\hline RDI & \multicolumn{3}{|c|}{$\mathbf{1 4 0 0}$ kcal } \\
\hline \% from RDI & $89 \%$ & $153 \%$ & $33 \%$ \\
\hline Protein (g) & $15.9 \pm 0.2$ & $55.9 \pm 1.8$ & $10.5 \pm 0.4$ \\
\hline RDI & \multicolumn{3}{|c|}{$294 \%$} \\
\hline \% from RDI & $84 \%$ & $\mathbf{1 3 0} \mathbf{g}$ & $55 \%$ \\
\hline Carbohydrate (g) & $106.0 \pm 1.3$ & $331.2 \pm 13.8$ & $70.4 \pm 2.5$ \\
\hline RDI & $82 \%$ & $255 \%$ & $54 \%$ \\
\hline \% from RDI & $30.3 \pm 1.2$ & $65.4 \pm 16.8$ & $12.5 \pm 4.0$ \\
\hline Fat (g) & $87 \%$ & $\mathbf{3 5 g}$ \\
\hline RDI & $187 \%$ & $36 \%$ \\
\hline \% from RDI & \multicolumn{3}{|c|}{} \\
\hline
\end{tabular}

RDA according $\mathrm{WHO}$ (2004)

Table (4) Mean and percent from RDA of Micronutrients intake for normal cases, obese and underweight children $(\mathrm{No}=30$ / each)

\begin{tabular}{|c|c|c|c|}
\hline \multicolumn{4}{|c|}{ Micronutrients intake } \\
\hline $\begin{array}{c}\text { Parameters/ } \\
\text { Groups }\end{array}$ & $\begin{array}{l}\text { Normal } \\
\text { G1 }\end{array}$ & $\begin{array}{c}\text { Obesity } \\
\text { G2 }\end{array}$ & $\begin{array}{c}\text { Underweight } \\
\text { G3 }\end{array}$ \\
\hline Iron $(\mathrm{mg})$ & $7.9 \pm 0.7$ & $9.9 \pm 2.1$ & $1.9 \pm 0.5$ \\
\hline RDI & \multicolumn{3}{|c|}{$10 \mathrm{mg}$} \\
\hline \% from RDI & $79 \%$ & $99 \%$ & $19 \%$ \\
\hline Zinc (mg) & $3.7 \pm 0.5$ & $6.7 \pm 1.5$ & $1.3 \pm 0.6$ \\
\hline RDI & \multicolumn{3}{|c|}{$5 \mathrm{mg}$} \\
\hline \% from RDI & $74 \%$ & $134 \%$ & $26 \%$ \\
\hline Calcium (mg) & $725.0 \pm 23.6$ & $327.7 \pm 17.6$ & $128.1 \pm 6.2$ \\
\hline RDI & \multicolumn{3}{|c|}{$1000 \mathrm{mg}$} \\
\hline \% from RDI & $73 \%$ & $33 \%$ & $13 \%$ \\
\hline $\begin{array}{l}\text { Phosphorus } \\
\text { (mg) }\end{array}$ & $254.0 \pm 8.0$ & $628.3 \pm 25.4$ & $162.3 \pm 11.1$ \\
\hline RDI & \multicolumn{3}{|c|}{$500 \mathrm{mg}$} \\
\hline \% from RDI & $51 \%$ & $126 \%$ & $33 \%$ \\
\hline Vit D $(\mu \mathrm{g})$ & $520.0 \pm 6.2$ & $445.0 \pm 7.7$ & $426.7 \pm 4.6$ \\
\hline RDI & \multicolumn{3}{|c|}{$600 \mu \mathrm{g}$} \\
\hline \% from RDI & $87 \%$ & $74 \%$ & $71 \%$ \\
\hline
\end{tabular}




\section{Table (5) Diet History for all Subjects}

\begin{tabular}{|c|c|c|c|c|c|c|c|c|c|c|c|c|c|c|c|c|c|c|c|c|c|c|c|c|c|c|c|c|c|c|}
\hline \multirow{4}{*}{$\begin{array}{l}\text { Food and } \\
\text { Beverage } \\
\text { Bread } \\
\end{array}$} & \multicolumn{10}{|c|}{ Frequency of consumption normal $(\mathrm{N}=30)$} & \multicolumn{10}{|c|}{ Frequency of consumption obese $(\mathrm{N}=30)$} & \multicolumn{10}{|c|}{ Frequency of consumption underweight $(\mathrm{N}=30)$} \\
\hline & \multicolumn{2}{|c|}{$\mathrm{D}$} & \multirow{2}{*}{\multicolumn{2}{|c|}{$\%$}} & \multicolumn{2}{|c|}{ W } & \multirow{2}{*}{\multicolumn{2}{|c|}{$\%$}} & \multirow{3}{*}{$\begin{array}{c}\mathrm{M} \\
-- \\
\end{array}$} & \multirow{3}{*}{$\%$} & \multicolumn{2}{|c|}{$\mathrm{D}$} & \multirow{2}{*}{\multicolumn{2}{|c|}{$\%$}} & \multicolumn{2}{|c|}{$\mathrm{W}$} & \multirow{2}{*}{\multicolumn{2}{|c|}{$\%$}} & \multirow{3}{*}{$\begin{array}{c}\text { M } \\
--\end{array}$} & \multirow{3}{*}{$\%$} & \multicolumn{2}{|c|}{$\mathrm{D}$} & \multirow{2}{*}{\multicolumn{2}{|c|}{$\%$}} & \multicolumn{2}{|c|}{ W } & \multirow{2}{*}{\multicolumn{2}{|c|}{$\%$}} & \multirow{3}{*}{$\begin{array}{c}\text { M } \\
-- \\
\end{array}$} & \multirow{3}{*}{$\%$} \\
\hline & $<3$ & $>3$ & & & $<3$ & $>3$ & & & & & $<3$ & $>3$ & & & $<3$ & $>3$ & & & & & $<3$ & $>3$ & & & $<3$ & $>3$ & & & & \\
\hline & 25 & -- & 83 & -- & -- & -- & -- & -- & & & 25 & -- & 83 & -- & -- & -- & -- & -- & & & -- & 15 & -- & 50 & -- & -- & -- & -- & & \\
\hline Rice & -- & 25 & -- & 83 & -- & & -- & & -- & -- & 30 & -- & 100 & -- & -- & -- & -- & -- & -- & -- & -- & -- & -- & -- & -- & 20 & -- & 67 & -- & -- \\
\hline Baked & -- & -- & -- & -- & 5 & -- & 17 & -- & -- & -- & 26 & -- & 87 & -- & -- & -- & -- & -- & -- & -- & -- & -- & -- & -- & 10 & -- & 33 & -- & -- & -- \\
\hline Indomie & -- & -- & -- & -- & 5 & -- & 17 & -- & -- & -- & 30 & -- & 100 & -- & -- & -- & -- & -- & -- & -- & -- & -- & -- & -- & 27 & -- & 90 & -- & -- & -- \\
\hline Potatos & -- & 20 & -- & 67 & -- & & -- & & -- & -- & 28 & -- & 93 & -- & -- & -- & -- & -- & -- & -- & -- & -- & -- & -- & -- & 10 & -- & 33 & -- & -- \\
\hline Potatol & -- & -- & -- & -- & -- & -- & -- & -- & -- & -- & -- & -- & -- & -- & -- & -- & -- & -- & 5 & 17 & -- & -- & -- & -- & -- & -- & -- & -- & -- & -- \\
\hline Chipsey & -- & -- & -- & -- & 15 & -- & 50 & -- & -- & -- & 30 & -- & 100 & -- & -- & -- & -- & -- & -- & -- & -- & -- & -- & -- & 27 & -- & 90 & -- & -- & -- \\
\hline Bean & -- & -- & -- & -- & 10 & -- & 33 & -- & -- & -- & -- & -- & -- & -- & 10 & -- & 33 & -- & -- & -- & -- & -- & -- & -- & 10 & -- & 33 & -- & -- & -- \\
\hline Falafel & -- & -- & -- & -- & 20 & & 67 & & -- & -- & -- & -- & -- & -- & -- & 16 & -- & 53 & -- & -- & -- & -- & -- & -- & -- & 8 & -- & 27 & -- & -- \\
\hline Lima bean & -- & -- & -- & -- & 15 & -- & 50 & -- & -- & -- & -- & -- & -- & -- & -- & -- & -- & -- & 20 & 67 & -- & -- & -- & -- & -- & -- & -- & -- & -- & -- \\
\hline Lentil & -- & -- & -- & -- & -- & -- & -- & -- & 20 & 67 & -- & -- & -- & -- & -- & -- & -- & -- & -- & -- & -- & -- & -- & -- & -- & -- & -- & -- & -- & -- \\
\hline $\begin{array}{l}\text { Fresh } \\
\text { vegetables }\end{array}$ & -- & 25 & -- & 83 & -- & & -- & & -- & -- & -- & -- & -- & -- & -- & 5 & & 17 & -- & -- & -- & -- & -- & -- & -- & 20 & -- & 67 & -- & -- \\
\hline $\begin{array}{l}\text { Cooked } \\
\text { vegetables }\end{array}$ & -- & 27 & -- & 90 & -- & & -- & & -- & -- & -- & -- & -- & -- & 8 & -- & 27 & -- & -- & -- & -- & -- & -- & -- & -- & 15 & -- & 50 & -- & -- \\
\hline Fruits & 26 & -- & 87 & -- & -- & -- & -- & -- & -- & -- & -- & -- & -- & -- & 10 & -- & 33 & -- & -- & -- & 10 & -- & 33 & -- & -- & -- & -- & -- & -- & -- \\
\hline Juices & -- & -- & -- & -- & 22 & -- & 73 & -- & -- & -- & -- & -- & -- & -- & -- & 16 & -- & 53 & -- & -- & -- & -- & -- & -- & 7 & -- & 23 & -- & -- & -- \\
\hline Meat & -- & 26 & -- & 87 & -- & & -- & & -- & -- & -- & 5 & -- & 17 & 2 & -- & 7 & -- & 23 & 77 & -- & -- & -- & -- & -- & 8 & -- & 27 & -- & -- \\
\hline $\begin{array}{l}\text { Processed } \\
\text { meat }\end{array}$ & -- & & -- & & -- & -- & -- & -- & 20 & 67 & 20 & -- & 67 & -- & -- & -- & -- & -- & -- & -- & -- & 19 & -- & 63 & -- & -- & -- & -- & -- & -- \\
\hline Liver & -- & -- & -- & -- & 20 & -- & 67 & -- & -- & -- & -- & -- & -- & -- & -- & -- & -- & -- & 5 & 17 & -- & -- & -- & -- & -- & -- & -- & -- & -- & -- \\
\hline Birds & -- & 18 & -- & 60 & & -- & -- & & -- & -- & -- & -- & -- & -- & -- & 4 & -- & 13 & -- & -- & -- & -- & -- & -- & 8 & -- & 27 & -- & -- & -- \\
\hline Fish & -- & & -- & & -- & -- & -- & -- & -- & -- & -- & -- & -- & -- & -- & -- & -- & -- & -- & -- & -- & -- & -- & -- & -- & -- & -- & -- & -- & -- \\
\hline
\end{tabular}




\section{Eating habits and their Associations with Obesity and Underweight in preschool children}

Nahla Ali ABD-Elrahman, Sonia Saleh El Marasy, Afaf Abd El Fattah Tawfik, Hanaa Hussein Elsayd and Alaa Osama Aboraya

\begin{tabular}{|c|c|c|c|c|c|c|c|c|c|c|c|c|c|c|c|c|c|c|c|c|c|c|c|c|c|c|c|c|c|c|}
\hline High fat fish & -- & -- & -- & -- & -- & -- & -- & -- & -- & -- & -- & -- & -- & -- & -- & -- & -- & -- & -- & -- & -- & -- & -- & -- & -- & -- & -- & -- & -- & -- \\
\hline Tilapia fish & -- & 24 & -- & 80 & & -- & -- & & -- & -- & -- & -- & -- & -- & 3 & -- & 10 & -- & -- & -- & -- & -- & -- & -- & 6 & -- & 20 & -- & -- & -- \\
\hline Milk & -- & 25 & -- & 83 & -- & & -- & & -- & -- & -- & -- & -- & -- & -- & 6 & -- & 20 & -- & -- & -- & -- & -- & -- & -- & 5 & -- & 17 & -- & -- \\
\hline White cheese & 25 & & 83 & & -- & -- & -- & -- & -- & -- & -- & 13 & -- & 43 & -- & -- & -- & -- & -- & -- & -- & 3 & -- & 10 & -- & -- & -- & -- & -- & -- \\
\hline $\begin{array}{l}\text { Triangles' } \\
\text { cheese }\end{array}$ & -- & -- & -- & -- & -- & -- & -- & -- & -- & -- & 25 & -- & 83 & -- & -- & -- & -- & -- & -- & -- & -- & -- & -- & -- & -- & -- & -- & -- & -- & -- \\
\hline Yogurt & -- & 26 & -- & 87 & & -- & & -- & -- & -- & -- & -- & -- & -- & 10 & -- & 33 & --- & -- & -- & -- & -- & -- & -- & 5 & -- & 17 & ---- & -- & -- \\
\hline Egg & 25 & -- & 83 & -- & -- & & -- & & -- & -- & -- & 22 & -- & 73 & -- & -- & -- & -- & 15 & 50 & -- & -- & -- & -- & -- & 7 & -- & 23 & -- & -- \\
\hline Sugar & & 20 & & 67 & -- & -- & -- & -- & -- & -- & 30 & -- & 100 & -- & -- & -- & -- & -- & -- & -- & 17 & & 57 & -- & -- & -- & -- & -- & -- & -- \\
\hline Dessert & -- & -- & -- & -- & & 15 & & 50 & -- & -- & 29 & -- & 87 & -- & -- & -- & -- & -- & -- & -- & -- & -- & -- & -- & 6 & -- & 20 & -- & -- & -- \\
\hline Sweets & -- & & -- & & -- & 10 & -- & 33 & -- & -- & 28 & -- & 93 & -- & -- & -- & -- & -- & -- & -- & -- & 15 & -- & 50 & -- & -- & -- & -- & -- & -- \\
\hline Honey & -- & -- & -- & -- & -- & -- & -- & -- & 15 & 50 & -- & 18 & -- & 60 & -- & -- & -- & -- & -- & -- & -- & -- & -- & -- & -- & -- & -- & -- & -- & -- \\
\hline Jam & -- & -- & -- & -- & -- & -- & -- & -- & 10 & 33 & -- & 22 & -- & 73 & -- & -- & -- & -- & -- & -- & -- & -- & -- & -- & -- & -- & -- & -- & 10 & 33 \\
\hline Salt & -- & 27 & -- & 90 & -- & -- & -- & -- & -- & -- & -- & 30 & -- & 100 & -- & -- & -- & -- & -- & -- & -- & 14 & -- & 47 & -- & -- & -- & -- & -- & -- \\
\hline $\begin{array}{l}\text { Stimulant } \\
\text { drinks }\end{array}$ & -- & & -- & & -- & 10 & -- & 33 & -- & -- & -- & 25 & -- & 83 & -- & -- & -- & -- & -- & -- & --- & 17 & -- & 57 & -- & -- & -- & -- & -- & -- \\
\hline Soft drinks & & -- & & -- & -- & 10 & -- & 33 & -- & -- & 30 & -- & 100 & -- & -- & -- & -- & -- & -- & -- & 20 & -- & 67 & -- & -- & -- & -- & -- & -- & -- \\
\hline Fast food & -- & -- & -- & -- & -- & -- & -- & -- & 5 & 17 & 27 & -- & 90 & --- & -- & -- & -- & -- & -- & -- & -- & -- & -- & -- & -- & -- & -- & -- & -- & -- \\
\hline Hot oil & -- & -- & -- & -- & -- & -- & -- & -- & -- & -- & -- & -- & -- & -- & -- & -- & -- & -- & -- & -- & -- & -- & -- & -- & -- & -- & -- & -- & -- & -- \\
\hline Corn oil & -- & 30 & -- & 100 & -- & -- & -- & -- & -- & -- & -- & 22 & -- & 73 & -- & -- & -- & -- & -- & -- & -- & --- & -- & -- & -- & 15 & 50 & -- & -- & -- \\
\hline $\begin{array}{l}\text { Hydrogenated } \\
\text { oils }\end{array}$ & & -- & -- & -- & -- & -- & -- & -- & -- & -- & & -- & -- & -- & -- & -- & -- & -- & -- & -- & -- & -- & -- & -- & -- & -- & -- & -- & -- & -- \\
\hline
\end{tabular}

$D=$ Daly; $W=$ weekly and $M=$ Monthly 
Table (6) mean of hemoglobin (Hb), TSH, T3, T4, and Vit A, and D serum for normal cases; obese and underweight children $(\mathrm{No}=30 /$ each $)$

\begin{tabular}{|l|c|c|c|c|}
\hline $\begin{array}{l}\text { Parameters/ } \\
\text { Groups }\end{array}$ & Normal range & $\begin{array}{c}\text { Normal/ } \\
\text { control } \\
\text { G1 }\end{array}$ & $\begin{array}{c}\text { Obesity } \\
\text { G2 }\end{array}$ & $\begin{array}{c}\text { Underweight } \\
\text { G3 }\end{array}$ \\
\hline Hb g/dl & $11-14$ & $12.1 \pm 0.06$ & $10.5 \pm 0.2$ & $9.7 \pm 0.1$ \\
\hline $\begin{array}{l}\text { \% change for } \\
\text { normal }\end{array}$ & -- & $-13 \%$ & $-20 \%$ \\
\hline TSH mIU/L & $\mathbf{( 0 . 4 - 7 . 0 )}$ & $3.78 \pm 0.3$ & $3.7 \pm 0.1$ & $2.5 \pm 0.1$ \\
\hline $\begin{array}{l}\text { \% change for } \\
\text { normal }\end{array}$ & & -- & $-2 \%$ & $-34 \%$ \\
\hline T3 $\mathbf{m I U / L}$ & $0.6-1.85$ & $1.1 \pm 0.04$ & $0.5 \pm 0.01$ & $0.2 \pm 0.01$ \\
\hline $\begin{array}{l}\text { \% change for } \\
\text { normal }\end{array}$ & -- & $-55 \%$ & $-82 \%$ \\
\hline T4 $\mathbf{m I U / L}$ & $\mathbf{4 . 8}-\mathbf{1 2 . 0}$ & $7.7 \pm 0.3$ & $7.7 \pm 0.1$ & $13.0 \pm 0.1$ \\
\hline $\begin{array}{l}\text { \% change for } \\
\text { normal }\end{array}$ & & -- & $0 \%$ & $69 \%$ \\
\hline Vit A $\boldsymbol{\mu g} / \mathbf{d l}$ & $11.3-64.7$ & $35.7 \pm 2.3$ & $9.6 \pm 0.2$ & $9.5 \pm 0.2$ \\
\hline $\begin{array}{l}\text { \% change for } \\
\text { normal }\end{array}$ & & -- & $-73 \%$ & $-73 \%$ \\
\hline Vit D ng/ ml & $>=30$ & $32.1 \pm 0.2$ & $14.3 \pm 0.4$ & $16.5 \pm 0.5$ \\
\hline $\begin{array}{l}\text { \% change for } \\
\text { normal }\end{array}$ & & -- & $-55 \%$ & $-49 \%$ \\
\hline
\end{tabular}




\title{
عادات تناول الطعام وارتباطها بالسمنه ونقص الوزن لاي أطفال ما قبل المدرسة
}

\author{
* نهلة علي عبا الرحمن **سونيا صالح المراسي، * عفاف عبد الفتاح توفيق، \\ *ناء حسين السيا و**الاء اسامه ابو ريه *
}

\author{
* المعهز القومي للتغذية

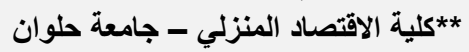

تظل العادات الغذائية الخاطئة مشكلة خطبرة للأطفال دون سن الخامسة. بيؤدي تناول الطعام السبئ

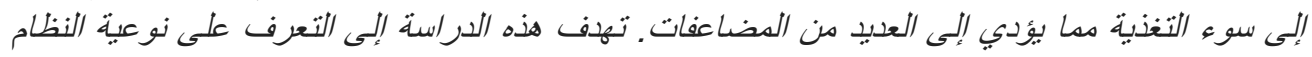

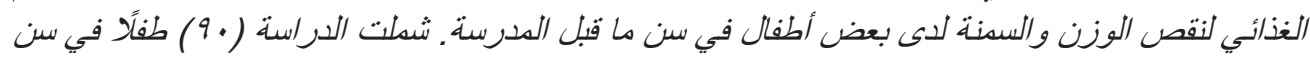

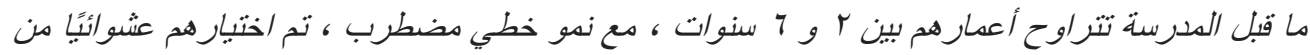

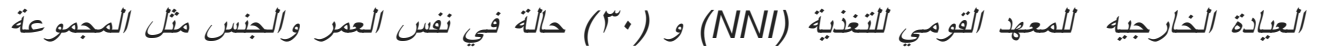

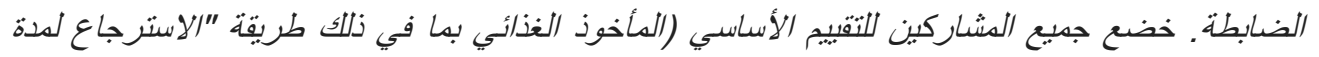

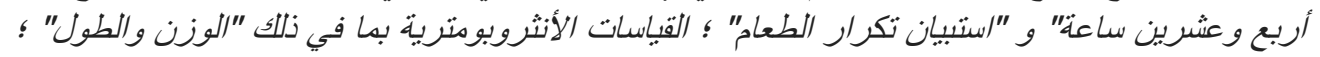

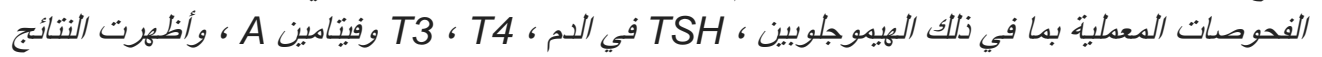

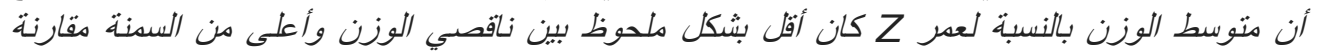

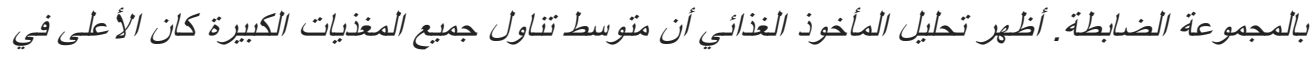

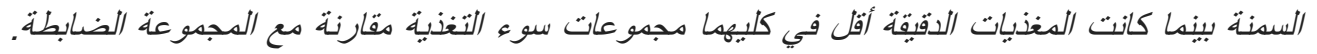

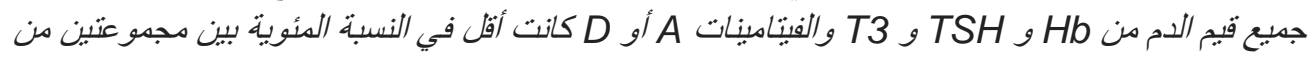

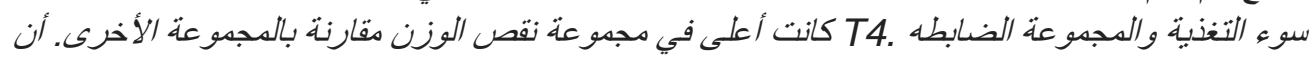

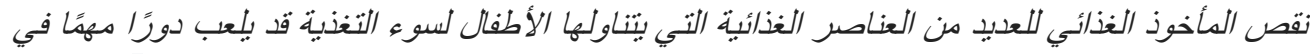

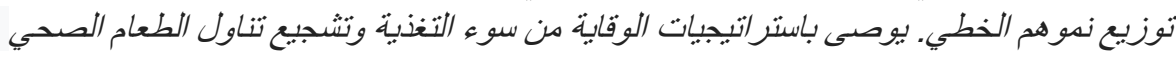
الكلمات المفتاحية: جوده النظام الغذائى - سوء التغذية ـ اطفال فى سن ما قبل الددرسة 